\title{
Metabolic actions of insulin-like growth factor II in cultured adult rat hepatocytes are not mediated through the insulin-like growth factor II receptor
}

\author{
H.Hartmann ${ }^{1}$, A.Meyer-Alber ${ }^{1}$ and T. Braulke ${ }^{2}$ \\ ${ }^{1}$ Department of Medicine, Division of Gastroenterology and Endocrinology, and ${ }^{2}$ Institute for Biochemistry II, \\ Georg-August-Universität, Göttingen, FRG
}

\begin{abstract}
Summary. Short- and long-term regulation of hepatic carbohydrate metabolism by insulin-like growth factor II was studied in primary cultures of adult rat hepatocytes and compared to the metabolic potency of insulin. Insulin-like growth factor II stimulated glycogen synthesis from $\left[{ }^{14} \mathrm{C}\right]$ glucose, uptake of $\left[{ }^{3} \mathrm{H}\right]$ aminoisobutyric acid and $\left[{ }^{14} \mathrm{C}\right]$ lactate formation from $\left[{ }^{14} \mathrm{C}\right]$ glucose up to three-fold. Basal glycogenolysis was inhibited to about $10 \%$, and glucagon-activated glycogenolysis was blocked completely. The enzymatic activity of glucokinase and pyruvate kinase was induced two-fold, the glucagon-dependent induction of phosphoenolpyruvate carboxykinase was antagonized. Compared to insulin, half-maximal responses required up to 50 times higher insulin-like growth factor II concentrations ranging from 10 $20 \mathrm{nmol} / \mathrm{l}$. A similar difference was observed for binding affinity of insulin-like growth factor II to the insulin receptor. The interaction with the insulin-like growth factor II/man-
\end{abstract}

nose 6-phosphate (IGF-II/Man-6-P) receptor was examined by studying ${ }^{125}$ I-insulin-like growth factor II binding and uptake of lysosomal enzymes. The affinity of insulin-like growth factor II to the IGF-II/Man-6-P receptor was considerably higher than for the insulin receptor. Antibodies against the IGF-II/Man-6-P receptor did not affect metabolic responses to insulin-like growth factor II, while binding to its receptor and the receptor-mediated endocytosis of arylsulphatase A were strongly inhibited. Thus, in adult rat liver insulin-like growth factor II appeared to exert metabolic actions not via interaction with its own receptor but through low affinity binding to hepatic insulin receptors.

Key words: insulin-like growth factor II, rat hepatocyte culture, liver metabolism, hepatic endocytosis, lysosomal enzymes, insulin binding, insulin-like growth factor II binding, insulin-like growth factor II receptor.
Insulin-like growth factor II (IGF-II) is a polypeptide hormone with structural homologies to insulin and to insulinlike growth factor I (IGF-I) [1,2]. Whereas several biological functions have been ascribed to these latter hormones, the physiological role of IGF-II, especially in humans, is not understood. In the rat, IGF-II may contribute to the development of embryonic tissues, particularly those of mesodermal origin, while post-natally, plasma levels of IGF-II decrease and tissue IGF-II m-RNA expression is apparently switched off [3, 4]. Recently, direct evidence for a physiological role of IGF-II in rodent embryonic growth was provided by studies where the IGF-II gene was disrupted by gene targetting [5].

Acute metabolic actions of IGF-II, e. g. hypoglycaemia and stimulation of glycogen synthesis, have been demonstrated in vivo and in vitro, resembling rapid metabolic effects of insulin $[6,7]$. IGF-II was shown to bind with high affinity to its putative receptor, a plasma membrane protein with an apparent molecular weight of about 300 kilodaltons $(\mathrm{kDa})$. However, since IGF-II can bind with lower affinity to receptors for insulin and IGF-I, proliferative and metabolic responses were believed not to depend solely on interaction of IGF-II with its own receptor [810]. This latter receptor is identical to the cation-independent mannose 6-phosphate (Man-6-P) receptor that mediates (1) Man-6-P-dependent transport of newly synthesized lysosomal enzymes from the Golgi apparatus to pre-lysosomes and (2) endocytosis of Man-6-P-containing ligands $[11,12]$. In contrast to insulin and IGF-I receptors the IGF-II/Man-6-P receptor lacks an intrinsic tyrosine kinase activity [13]. Some reports suggested that biological responses to IGF-II occur via the IGF-II/Man-6-P receptor including stimulatory actions on glycogen synthesis in a human hepatoma (HEP-G2) cell line [13], amino acid uptake in cultured human myoblasts [14], $\mathrm{Ca}^{2+}$ influx in competent Balb/c 3T3 cells [15], inositol triphosphate formation in basolateral membranes of proximal tubular kidney cells [16] and DNA synthesis in a human erythroleukaemia cell line [17]. A recent report of IGF-II-stimulated coupling of the human IGF-II/Man-6-P receptor to a $\mathrm{G}_{\mathrm{i}^{-}}$ 
protein may provide a mechanism for signal transduction [18]. In contrast, several other studies have led to the conclusion that cellular IGF-II responses may be mediated through either the insulin or IGF-I receptor [8, 19-22]. In the present work the role of the IGF-II/Man-6-P receptor for short- and long-term metabolic responses to IGF-II was studied in cultured hepatocytes isolated from adult rats, that express the insulin and the IGF-II/Man-6-P receptor, while the IGF-I receptor is virtually absent [23].

\section{Materials and methods}

\section{Materials}

Chemicals were reagent grade and from commercial sources. Human recombinant IGF-II was a gift from Ciba-Geigy AG (Basel, Switzerland); porcine insulin, dexamethasone and Man-6-P (sodium salt) were obtained from Sigma Chemical Co. (Deisenhofen, FRG). Enzymes, fetal calf serum and M 199 medium were purchased from Boehringer Mannheim GmbH (Mannheim, FRG); bovine serum albumin (BSA) was from Paesel and Lorei GmbH and Co. (Frankfurt, FRG), glucagon and antibiotics from Serva Feinbiochemica and Co. (Heidelberg, FRG). Collagenase was obtained from Worthington (Berlin, FRG), D- $\left[\mathrm{U}-{ }^{14} \mathrm{C}\right] \mathrm{glucose}$ (specific activity $2.9 \mathrm{mCi} / \mathrm{mmol}$ ), $\left[{ }^{3} \mathrm{H}\right]$-labelled aminoisobutyric acid (specific activity $13.4 \mathrm{Ci} / \mathrm{mmol}$ ) and $\left[{ }^{14} \mathrm{C}\right]$-labelled molecular mass standards from Du Pont New England Nuclear (Dreieich, FRG). Carrier-free $\left[{ }^{125}\right.$ I]iodine, $\left.{ }^{35} \mathrm{~S}\right]$ methionine (specific activity $1100 \mathrm{Ci} / \mathrm{mmol}$ ) and monoiodinated porcine (Tyr-A14)- $\left[{ }^{125} \mathrm{I}\right]$-labelled insulin $(\sim 2000 \mathrm{Ci} / \mathrm{mmol})$ were purchased from Amersham Buchler (Braunschweig, FRG). IGF-II was iodinated by the chloramine $\mathrm{T}$ procedure to a specific activity of $500-700 \mathrm{Ci} / \mathrm{mmol}$. Arylsulphatase A antiserum was raised by immunizing a goat with purified human placental arylsulphatase A [24]. The antiserum directed against the IGF-II/Man-6-P receptor purified from human liver was obtained after immunization of a goat as described previously [25]. Formaldehyde-fixed Staphylococcus aureus cell wall preparation (Pansorbin) was from Calbiochem ( $\mathrm{La}$ Jolla, Calif., USA).

\section{Cell culture}

Hepatocytes were isolated with collagenase from livers of fed male Wistar rats (obtained from Mus Rattus, Brunnthal, FRG) by a recirculating in situ perfusion technique as previously described [26]. Cells were suspended in M 199 medium, containing $5 \mathrm{mmol} / \mathrm{l}$ glucose, supplemented with dexamethasone $(0.1 \mu \mathrm{mol} / \mathrm{l})$, insulin $(1 \mathrm{nmol} / \mathrm{l})$ and $0.2 \%$ (weight/volume, w/v) BSA and cultured on 35 or $60 \mathrm{~mm}$ Falcon plastic dishes. For the first $3 \mathrm{~h}$ of culture, the medium was also supplemented with $4 \%$ ( $/ / v)$ fetal calf serum. After $3 \mathrm{~h}$ the medium was replaced by serum-free medium. The medium was changed again at $24 \mathrm{~h}$ and $48 \mathrm{~h}$ of culture. The gas atmosphere contained $5 \%(\mathrm{v} / \mathrm{v}) \mathrm{CO}_{2}, 20 \% \mathrm{O}_{2}$ and $75 \% \mathrm{~N}_{2}$.

\section{Binding studies}

Cells were cultured for $48 \mathrm{~h}$. After washing the cells with M 199 medium, binding studies of ${ }^{125} \mathrm{I}$-insulin and ${ }^{125} \mathrm{I}$-IGF-II were performed according to the method of Fleig et al. [27] at $37^{\circ} \mathrm{C}$ and $4^{\circ} \mathrm{C}$ respectively. Briefly, cells were pre-incubated in serum-free M 199 medium supplemented with $2 \mathrm{mmol} / \mathrm{l}$ lactate and $0.1 \mu \mathrm{mol} / \mathrm{l}$ dexamethasone for $1 \mathrm{~h}$ followed by the addition of ${ }^{125} \mathrm{I}$-insulin or ${ }^{125} \mathrm{I}-\mathrm{IGF}-\mathrm{II}$ $(\sim 0.05 \mu \mathrm{Ci} /$ dish, hormone concentration $10-20 \mathrm{pmol} / \mathrm{l})$ with or without various concentrations of unlabelled insulin or IGF-II. Cells were incubated with ${ }^{125} \mathrm{I}$-insulin for $1 \mathrm{~h}$ at $37^{\circ} \mathrm{C}$ and for $6 \mathrm{~h}$ at $4^{\circ} \mathrm{C}$. IGF-II binding was assessed after $6 \mathrm{~h}$ incubations at $4^{\circ} \mathrm{C}$. Incubations were terminated by aspirating the medium and rapidly washing the monolayers five times with ice-cold phosphate-buffered saline pH $7.4\left(140 \mathrm{mmol} / 1 \mathrm{NaCl}, 2.6 \mathrm{mmol} / \mathrm{KCl}, 8 \mathrm{mmol} / 1 \mathrm{Na}_{2} \mathrm{HPO}_{4}\right.$, $\left.1.5 \mathrm{mmol} / \mathrm{K} \mathrm{KH}_{2} \mathrm{PO}_{4}\right)$. Aliquots of the medium were analysed for trichloroacetic acid (TCA)-soluble and -insoluble radioactivity to correct for ligand degradation. Cells were solubilized in $0.1 \%$ sodium dodecyl sulphate (SDS) and precipitated with TCA to correct for cell-associated degraded label [27]. Binding of ${ }^{125}$ I-insulin was corrected for unspecific binding (15-20\% of total bound radioactivity) determined in the presence of $10 \mu \mathrm{mol} / \mathrm{l}$ unlabelled insulin. Non-specific binding of IGF-II was below $15 \%$ of cell-associated ligand.

\section{Immunoprecipitation of IGF-IL/Man-6-P receptor and cross-linking of ${ }^{125} I-I G F-I I$ to hepatocytes}

After $32 \mathrm{~h}$ of culture, hepatocytes were labelled for $16 \mathrm{~h}$ with $\left.{ }^{35} \mathrm{~S}\right]$ methionine $(20 \mu \mathrm{Ci} / \mathrm{dish})$. Cells were solubilized in $10 \mathrm{mmol} / 1$ Tris/ $\mathrm{HCl}$ buffer $\mathrm{pH} 7.5$ containing $0.5 \mathrm{~mol} / \mathrm{l} \mathrm{NaCl}, 1.5 \%$ (w/v) Triton $\times 100,0.1 \%$ SDS, $1 \%$ sodium deoxycholate, $1 \%$ (w/v) BSA, $1 \mathrm{mmol} / 1 \mathrm{EDTA}, 1 \mathrm{mmol} / 1$ phenylmethylsulphonyl fluoride and $5 \mathrm{mmol} / \mathrm{l}$ iodoacete amide. The labelled IGF-II/Man-6-P receptor were immunoprecipitated by the aid of Pansorbin, solubilized and analysed by SDS/polyacrylamide (5\%) gel electrophoresis (PAGE) and fluorography as described previously [28]. Cell surface IGFIV/Man-6-P receptors were cross-linked to ${ }^{125}$ I-IGF-II as reported [29]. Briefly, $32 \mathrm{~h}$ pre-cultured hepatocytes were incubated for $16 \mathrm{~h}$ at $4^{\circ} \mathrm{C}$ with ${ }^{125} \mathrm{I}$-IGF-II $\left(10^{6} \mathrm{cpm} / \mathrm{dish}\right)$ in $0.1 \mathrm{~mol} / \mathrm{l}$ HEPES buffer $\mathrm{pH} 7.6$ containing $0.12 \mathrm{~mol} / 1 \mathrm{NaCl}, 5 \mathrm{mmol} / 1 \mathrm{KCl}, 1.2 \mathrm{mmol} / \mathrm{l}$ $\mathrm{MgSO}_{4}, 8 \mathrm{mmol} / /$ glucose and $0.1 \%$ (w/v) BSA. After washing in BSA-free buffer cross-linking was carried out with $0.5 \mathrm{mmol} / 1$ disuccinimidyl suberate. After $15 \mathrm{~min}$ the reaction was stopped by $0.15 \mathrm{~mol} / 1 \mathrm{Tris} / \mathrm{HCl} \mathrm{pH} 7.4$ containing $1.5 \mathrm{mmol} / \mathrm{l}$ EDTA. Cells were solubilized and analysed under reducing conditions by SDS/PAGE ( $5 \%$ polyacrylamide). Dried gels were autoradiographed using Hyperfilm MP (Amersham Buchler) and Lightning Plus intensifier screens (Du Pont). Alternatively, the IGF-II/Man-6-P receptor was cross-linked to ${ }^{125}$ I-IGF-II and immunoprecipitated from solubilized cells as described above.

\section{Glycogen synthesis}

Cells were cultured for $48 \mathrm{~h}$ in M 199 medium in the presence of insulin $(0.1 \mathrm{mmol} / \mathrm{l})$ and dexamethasone $(0.1 \mu \mathrm{mol} / \mathrm{l})$. After washing, hepatocytes were pre-incubated in the absence of insulin for $90 \mathrm{~min}$, medium was changed and supplemented with $2 \mathrm{mmol} / 1$ lactate and $\left[{ }^{14} \mathrm{C}\right]$ glucose $(\sim 0.8 \mu \mathrm{Ci} / \mathrm{dish})$ followed after $30 \mathrm{~min}$ by the addition of IGF-II or insulin. Incubations were terminated after $2 \mathrm{~h}$ by aspirating the medium and washing the cells with ice-cold phosphate buffered saline. Cells were kept in liquid nitrogen until analysis for radioactivity incorporated into glycogen. Glycogen was analysed using $\mathrm{KOH}$ and ethanol extraction [27]. Glycogen synthesis was linear for $3 \mathrm{~h}$.

\section{Aminoisobutyric acid $(A I B)$ transport}

After $48 \mathrm{~h}$ of culture cells were washed three times with M 199 medium, incubated for $120 \mathrm{~min}$ in the presence of IGF-II or insulin followed by the addition of $\left[{ }^{3} \mathrm{H}\right]$ aminoisobutyric acid (AIB $8 \mu \mathrm{mol} / 1$, $\sim 0.8 \mu \mathrm{Ci} /$ dish) and incubated for an additional $25 \mathrm{~min}$. After aspirating the medium and extensive washing with ice-cold phosphate buffered saline, cells were solubilized with $\mathrm{NaOH}(1 \mathrm{~mol} / \mathrm{l}, 1 \mathrm{ml} / \mathrm{dish})$ and AIB content determined as described [30]. AIB transport was linear for up to $50 \mathrm{~min}$. 

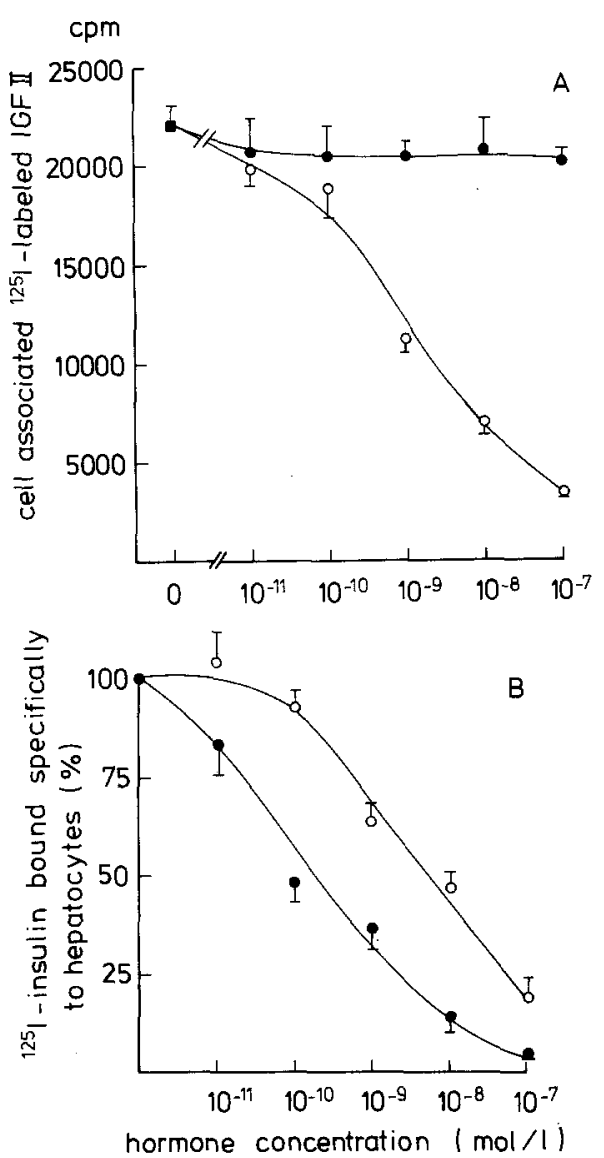

Fig.1 A, B. Binding of ${ }^{125} \mathrm{I}$-insulin-like growth factor II (IGF-II) and of ${ }^{125} \mathrm{I}$-insulin to cultured hepatocytes. Cells were pre-cultured for $48 \mathrm{~h}$ with dexamethasone $(0.1 \mu \mathrm{mol} / \mathrm{l})$ and insulin $(1 \mathrm{nmol} / \mathrm{l})$. A Competition of ${ }^{125}$ I-IGF-II binding by unlabelled IGF-II $(\mathrm{O}-\mathrm{O})$ or insulin $(\bullet)$ at the indicated concentrations. B Cells were incubated with ${ }^{125} \mathrm{I}$-insulin in the presence of unlabelled IGF-II $(O-O)$ or insulin (-) at the indicated concentrations. Specific binding was defined as the difference between cell-bound radioactivity in the absence of unlabelled ligands and the unspecific binding. Data are from a typical experiment with mean $\pm S D$ of triplicate samples at each concentration

\section{Glycolysis}

Hepatocytes cultured for 48 b were washed and incubated in insulinfree M 199 medium for $1 \mathrm{~h}$. The medium was then changed and supplemented with lactate $(2 \mathrm{mmol} / \mathrm{l})$ and $\left[{ }^{14} \mathrm{C}\right]$ glucose $(\sim 0.8 \mu \mathrm{Ci} / \mathrm{dish})$. After pre-incubation for $30 \mathrm{~min}$, zero time medium samples were taken, and the experiment started by the addition of insulin or IGFII at the respective concentrations. The incubation was terminated after $3 \mathrm{~h}$ by aspiration of the medium. Production of lactate was linear up to $240 \mathrm{~min}$ for insulin and IGF-II-stimulated cells. $\left[{ }^{14} \mathrm{C}\right] \mathrm{Lac}-$ tate generated from $\left[{ }^{14} \mathrm{C}\right]$ glucose was separated by ion-exchange chromatography [31].

\section{Glycogenolysis}

During 24 to $48 \mathrm{~h}$ of culture, $\left[{ }^{14} \mathrm{C}\right]$ glucose $(\sim 3 \mu \mathrm{Ci} /$ dish $)$ was incorporated into glycogen in the presence of $20 \mathrm{mmol} / \mathrm{l}$ glucose, $10 \mathrm{nmol} / \mathrm{l}$ insulin and $0.1 \mu \mathrm{mol} / \mathrm{l}$ dexamethasone. The remaining free labelled glucose was removed by three successive washings. The medium for the experiments contained $5 \mathrm{mmol} / /$ glucose, $2 \mathrm{mmol} / \mathrm{lac}$ tate, $0.1 \mu \mathrm{mol} / 1$ dexamethasone and insulin, IGF-II or glucagon. After pre-incubation for $30 \mathrm{~min}$ zero time medium samples were taken. The release of $\left[{ }^{14} \mathrm{C}\right]$ glucose was linear for $120 \mathrm{~min}$. $\left[{ }^{14} \mathrm{C}\right] \mathrm{Glu}$ cose was separated as described above.

\section{Enzyme induction}

Cells were processed for glucokinase and pyruvate kinase assays using an Ultra-Turrax homogenizer (Janke and Kunkel, Staufen, FRG) in $50 \mathrm{mmol} / 1 \mathrm{HEPES}, 100 \mathrm{mmol} / \mathrm{l} \mathrm{KCl}, 5 \mathrm{mmol} / 1 \mathrm{MgCl}_{2}$, $1 \mathrm{mmol} / \mathrm{l}$ EDTA, $2.5 \mathrm{mmol} / 1$ dithioerythritol and $10 \mathrm{mg} / \mathrm{ml} \mathrm{BSA}$ at $\mathrm{pH}$ 7.5. Enzyme activities were determined as described [31], with the addition of $0.1 \mathrm{mmol} / \mathrm{l}$ fructose 1,6 -bisphosphate in the pyruvate kinase assay. For the phosphoenolpyruvate carboxykinase assay, cells were homogenized in $50 \mathrm{mmol} / \mathrm{l}$ Tris $\mathrm{HCl}, \mathrm{pH} \mathrm{8.1}$, containing $0.40 \mathrm{mmol} / 1 \mathrm{MnCl}_{2}$ and $1 \mathrm{mmol} / \mathrm{l}$ dithioerythritol. Enzyme activity was measured according to Seubert and Huth [32] and DNA according to Oliver et al. [33].

\section{Internalization of $P^{35}$ SJmethionine-labelled arylsulphatase $A$}

$\mathrm{NH}_{4} \mathrm{Cl}$ secretions of $\left.{ }^{35} \mathrm{~S}\right]$ methionine-labelled baby hamster kidney cells transfected with the cDNA of human arylsulphatase $\mathrm{A}$ were prepared as described [34]. Hepatocytes were incubated for $30 \mathrm{~min}$ in M 199 medium, containing $20 \mathrm{mmol} / 1$ HEPES $\mathrm{pH} 7.2$ and $0.1 \%$ $(\mathrm{w} / \mathrm{v}) \mathrm{BSA}$ and for an additional $30 \mathrm{~min}$ in the absence or presence of IGF-II/Man-6-P receptor antiserum (5\% (v/v)). Thereafter, the cells were incubated for $60 \mathrm{~min}$ with labelled secretions in the absence or presence of receptor antiserum, Man-6-P $(5 \mathrm{mmol} / \mathrm{l})$ or IGF-II ( $100 \mathrm{nmol} / \mathrm{l})$. Following washing, arylsulphatase A was immunoprecipitated from cell lysates as described [35] and visualized after SDS/PAGE (10\% polyacrylamide) by fluorography.

\section{Results}

\section{Binding to cultured hepatocytes}

When cells were incubated with labelled IGF-II at $4^{\circ} \mathrm{C}$ about $25 \%$ of the total radioactivity was cell-associated with virtually no degradation observed of labelled ligand. Half-maximal displacement occurred at IGF-II concentrations of about $1 \mathrm{nmol} / \mathrm{l}$ (Fig. $1 \mathrm{~A}$ ). Non-specific binding was below $15 \%$ of cell-associated radioactivity. Addition of insulin at concentrations of up to $10 \mu \mathrm{mol} / 1 \mathrm{did}$ not result in displacement of labelled IGF-II (Fig.1A).

When cells were incubated with labelled insulin, about $10 \%$ of total radioactivity added was cell-associated. Both peptides displaced cell-associated insulin, however IGFII concentrations approximately 50 times higher were required for half-maximal displacement (about $0.2 \mathrm{nmol} / \mathrm{l}$ for insulin and about $10 \mathrm{nmol} / /$ for IGF-II; Fig.1B).

\section{Immunoprecipitation of IGF-IL/Man-6-P receptor and cross-linking of ${ }^{125} I-I G F-I I$ to hepatocytes}

The specificity of the antiserum directed against the human IGF-II/Man-6-P receptor was assayed by immunoprecipitation of metabolically-labelled hepatocytes and hepatocytes cross-linked to ${ }^{125}$ I-IGF-II. Immunoprecipitation of $\left.{ }^{35} \mathrm{~S}\right]$ methionine-labelled hepatocytes with the antiserum followed by SDS-PAGE under reducing conditions identified a protein band of about $300 \mathrm{kDa}$ (Fig. 2, lane 1 ). This protein co-migrated with a hepatocyte pro- 


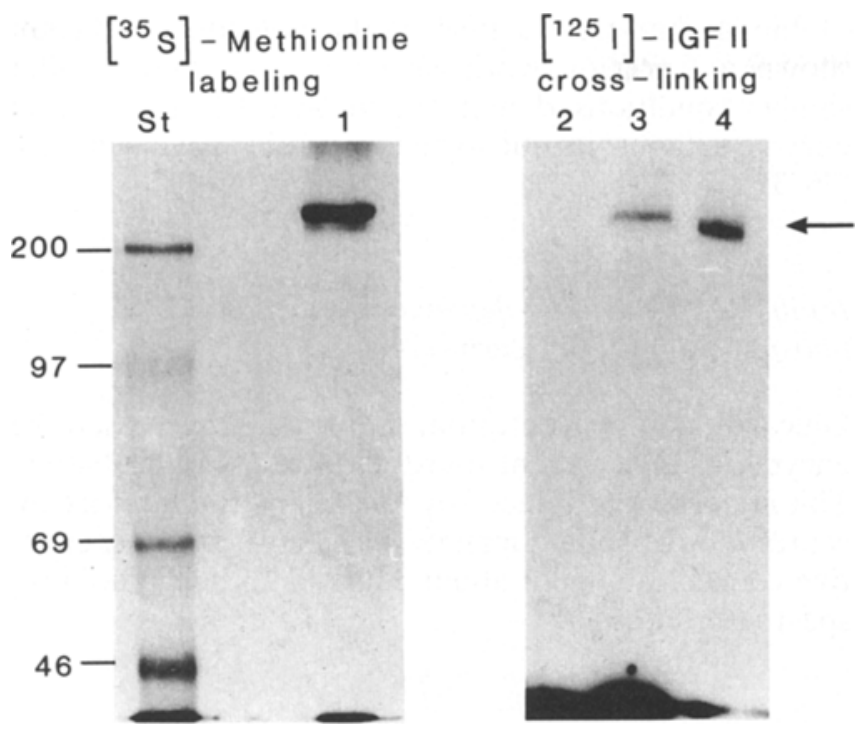

Fig. 2. Insulin-like growth factor II/mannose 6-phosphate (IGFII/Man-6-P) receptors in cultured hepatocytes. Cells were labelled for $16 \mathrm{~h}$ with [ $\left.{ }^{35} \mathrm{~S}\right] \mathrm{methionine}$ followed by immunoprecipitation of the IGF-II/Man-6-P receptor (lane 1). Alternatively, cells were incubated with ${ }^{125} \mathrm{I}-\mathrm{IGF}-\mathrm{II}\left(10^{6} \mathrm{cpm}\right)$ in the presence (lane 2$)$ or absence (lane 3$)$ of unlabelled IGF-II $(0.5 \mu \mathrm{g})$ and bound ${ }^{125}$ I-IGF-II was cross-linked with disuccinimidyl suberate. Cells were solubilized and analysed by sodium dodecyl sulphate/polyacrylamide gel electrophoresis. A parallel dish was incubated with labelled IGF-II $\left(3 \times 10^{6} \mathrm{cpm}\right)$ and followed by cross-linking and immunoprecipitation using IGF-II/Man-6-P receptor antiserum (lane 4). The positions of molecular mass markers (St, values in kilodaltons) and of the IGF-II/Man-6-P receptor $(\leftarrow)$ are indicated

tein cross-linked to ${ }^{125}$ I-IGF-II (Fig. 2, lane 3) and with the purified human IGF-II/Man-6-P receptor cross-linked to ${ }^{125}$ I-IGF-II (not shown). Remarkable labelling of smaller proteins was not observed. The major polypeptide to which ${ }^{125}$ I-IGF-II was cross-linked could be immunoprecipitated by the antiserum against the human IGF-II/ Man-6-P receptor (Fig. 2, lane 4). Complete competition for ${ }^{125} \mathrm{I}$-IGF-II binding occurred in the presence of an excess of unlabelled IGF-II (Fig.2, lane 2).

\section{Stimulation of glycogen synthesis}

IGF-II and insulin stimulated glycogen synthesis from $\left[{ }^{14} \mathrm{C}\right]$ glucose about three-fold (Fig. $3 \mathrm{~A}$ ). Half-maximal stimulation occurred at insulin concentrations of about $0.15 \mathrm{nmol} / 1$ and at IGF-II concentrations of about $10 \mathrm{nmol} / \mathrm{l}$ (Fig. $3 \mathrm{~A}$ ).

\section{Stimulation of AIB transport}

Transport of AIB was doubled by the addition of both peptides at maximally effective concentrations (Fig.3B). Half-maximal responses were observed at concentrations of insulin of about $0.8 \mathrm{nmol} / 1$ and of IGF-II of about $10 \mathrm{nmol} / \mathrm{l}$ (Fig. 3 B).

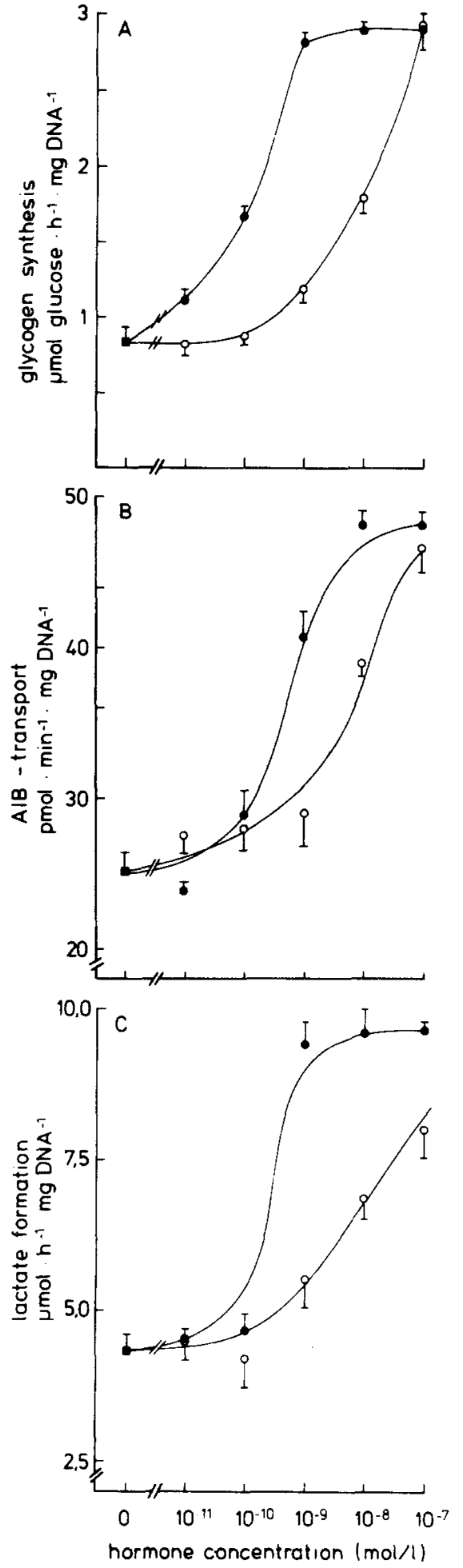

Fig.3A-C. Stimulation of glycogen synthesis (A), aminoisobutyric acid (AIB) transport (B) and glycolysis (C) by insulin-like growth factor II (IGF-II) and insulin in cultured hepatocytes. After $48 \mathrm{~h}$ of culturing in the presence of dexamethasone $(0.1 \mu \mathrm{mol} / 1)$ and insulin $(1 \mathrm{nmol} / 1)$ cells were washed and incubated at the indicated concentrations of IGF-II $\left(\mathrm{O}_{-} \mathrm{O}\right)$ or insulin $(\bullet)$. In A cells were kept for $120 \mathrm{~min}$ in the presence of $\left.{ }^{14} \mathrm{C}\right] \mathrm{glucose}(0.8 \mu \mathrm{Ci} / \mathrm{dish})$, in $\mathbf{B}$ for $25 \mathrm{~min}$ with $\left[{ }^{3} \mathrm{H}\right] \mathrm{AIB}(0.8 \mu \mathrm{Ci} / \mathrm{dish})$, and in $\mathbf{C}$ for $180 \mathrm{~min}$ with $\left[{ }^{14} \mathrm{C}\right]$ glucose $(0.8 \mu \mathrm{Ci} /$ dish $)$ as described in Materials and methods. Data are mean $\pm S D$ of typical experiments performed in triplicate at each concentration 

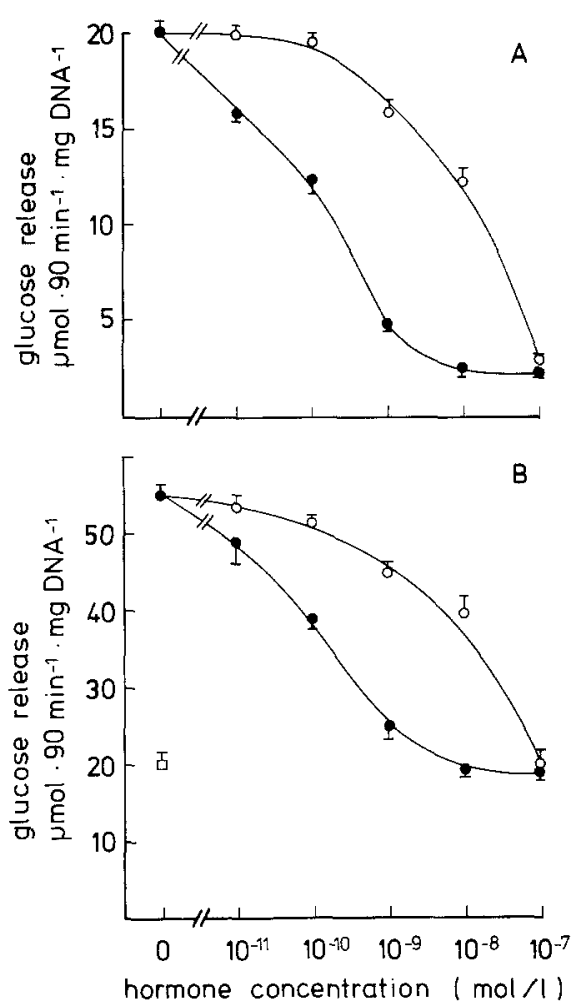

Fig.4A,B. Inhibition of basal (A) and glucagon-activated (B) glycogenolysis by insulin-like growth factor II and insulin in cultured hepatocytes. A Glycogen was pre-labelled by incubation of cultures with $\left[{ }^{14} \mathrm{C}\right]$ glucose from 24 to $48 \mathrm{~h}$. Subsequently cells were washed and kept at the indicated concentrations of IGF-II $(\mathrm{O}-\mathrm{O})$ or insulin $(-)$ ) for $90 \mathrm{~min}$. In $\mathbf{B}$ glycogenolysis was stimulated by glucagon $(0.1 \mathrm{nmol} / \mathrm{l})$. $\square$ indicates cells in the absence of glucagon. Data are mean \pm SD of typical experiments performed in triplicate at each concentration

\section{Stimulation of glycolysis}

Formation of $\left[{ }^{14} \mathrm{C}\right]$ lactate from $\left[{ }^{14} \mathrm{C}\right]$ glucose was stimulated more than two-fold by insulin and approximately two-fold by IGF-II. Half-maximally effective concentrations were approximately $0.2 \mathrm{nmol} / \mathrm{l}$ for insulin and in the range of about $15 \mathrm{nmol} / 1$ for IGF-II (Fig. $3 \mathrm{C}$ ). Compared to insulin an identical maximal response was not observed at the IGF-II concentrations tested.

\section{Inhibition of basal and glucagon-activated glycogenolysis}

Spontaneous release of $\left[{ }^{14} \mathrm{C}\right]$ glucose from labelled glycogen was reduced to approximately $10 \%$ (Fig. 4 A) and glucagon-activated release was suppressed completely by IGF-II and insulin (Fig.4B). Half-maximally effective concentrations were at least 50 times higher for IGF-II than for insulin.

\section{Induction of glucokinase and pyruvate kinase}

IGF-II and insulin added at high concentrations $(0.1 \mu \mathrm{mol} / \mathrm{l})$ increased the activities of glucokinase and pyruvate kinase after $48 \mathrm{~h}$ of culture about two-fold
(Table 1). The time course of the induction (data not shown) and previous work using specific antibodies under similar conditions demonstrated that the increase in enzyme activity was due to an increase in enzyme protein $[36,37]$.

\section{Inhibition of glucagon-dependent induction of phosphoenolpyruvate carboxykinase}

Glucagon at a concentration of $0.1 \mathrm{nmol} / 1$ increased the enzyme's activity about four-fold after a $4 \mathrm{~h}$ incubation. This increase was reduced by IGF-II and insulin in a concentration-dependent manner with half-maximally effective concentrations of about $2 \mathrm{nmol} / 1$ and $0.2 \mathrm{nmol} / 1 \mathrm{re}$ spectively (Fig.5).

Inhibition of endocytosis of arylsulphatase $A$ by antibodies against the IGF-IL/Man-6-P receptor

Previous work suggested that treatment of human fibroblasts with antibodies against the human IGF-II/Man-6-P receptor interferred with receptor functions in intracellular sorting and endocytosis of lysosomal enzymes [38]. Similarly, incubation of hepatocytes with 1 and $5 \%$ antiserum against the receptor inhibited the endocytosis of the Man-6-P-containing enzyme arylsulphatase $\mathrm{A}$ by about 70 and $84 \%$, respectively (Fig. 6, lane 3,4). Complete inhibition was observed in the presence of Man-6-P (Fig. 6, lane 2). In the presence of $100 \mathrm{nmol} / \mathrm{l} \mathrm{IGF-II} \mathrm{the} \mathrm{interna-}$ lization of arylsulphatase A was decreased by $54 \%$ (Fig. 6 , lane 5). Treatment of hepatocytes for $30 \mathrm{~min}$ with IGF-II $(100 \mathrm{nmol} / \mathrm{l})$ prior to the addition of arylsulphatase A reduced the endocytosis by about $90 \%$ compared to control cells (not shown).

\section{Effect of IGF-II/Man-6-P receptor antiserum on IGF-II binding and on IGF-II-stimulated glycogen synthesis}

When cells were incubated in the presence of $5 \%$ antiserum against the IGF-II/Man-6-P receptor the binding of ${ }^{125}$ I-IGF-II was inhibited by about $50 \%$ (Fig.7). At the same antiserum concentration stimulation of glycogen synthesis by insulin $(5 \mathrm{nmol} / \mathrm{l})$ and IGF-II $(0.1 \mu \mathrm{mol} / 1)$ was unaffected (Fig. 7).

Table 1. Induction of glucokinase and pyruvate kinase by insulinlike growth factor II (IGF-II) and insulin in cultured hepatocytes

\begin{tabular}{llr}
\hline Condition & \multicolumn{2}{l}{$\begin{array}{l}\text { Enzyme activity } \\
\left(\mu \mathrm{mol} \cdot \mathrm{min}^{-1} \cdot \mathrm{mg} \mathrm{DNA}^{-1}\right)\end{array}$} \\
\cline { 2 - 3 } & Glucokinase & Pyruvate kinase \\
\hline Control $^{\mathrm{a}}$ & $0.27 \pm 0.01$ & $6.62 \pm 0.22$ \\
IGF-II $^{\mathrm{b}}$ & $0.60 \pm 0.02$ & $12.65 \pm 0.62$ \\
Insulin $^{\mathrm{b}}$ & $0.55 \pm 0.04$ & $11.66 \pm 0.55$ \\
\hline
\end{tabular}

a insulin concentration $0.1 \mathrm{nmol} / \mathrm{l} ;{ }^{\mathrm{b}}$ hormone concentration $0.1 \mu \mathrm{mol} / 1$

Hepatocytes were cultured for $48 \mathrm{~h}$ with hormones added after $4 \mathrm{~h}$. Data are mean \pm SD from a typical experiment with six dishes each 


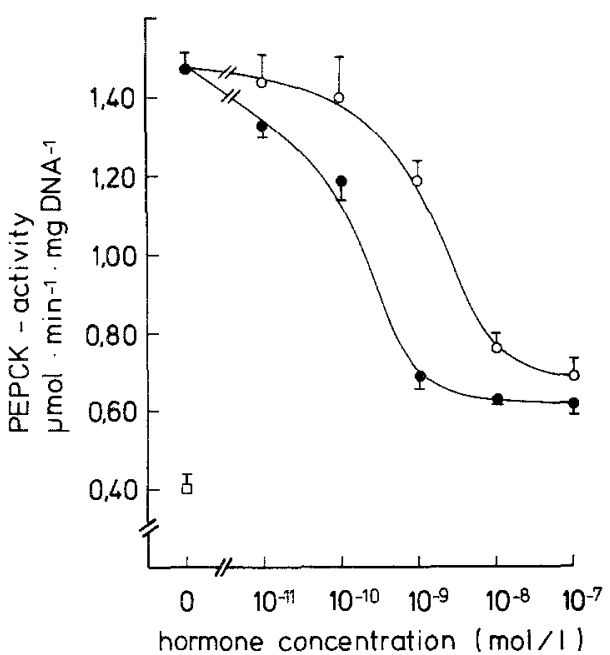

Fig. 5. Inhibition of glucagon-dependent increase of phosphoenolpyruvate carboxykinase (PEPCK) activity by insulin-like growth factor II (IGF-II) and insulin in cultured hepatocytes. Cells were cultured for $48 \mathrm{~h}$ in the presence of dexamethasone $(0.1 \mu \mathrm{mol} / \mathrm{l})$ and insulin $(1 \mathrm{nmol} / \mathrm{l})$. Thereafter, induction was performed with $0.1 \mathrm{nmol} / \mathrm{l}$ glucagon by incubating the cells for $4 \mathrm{~h}$. IGF-II $(\mathrm{O}-\mathrm{O})$ or insulin (-) were added at the indicated concentrations. $\square$ indicates enzyme activity in the absence of glucagon. Data are mean $\pm S D$ of a typical experiment performed in triplicate at each concentration

\section{Discussion}

The present work demonstrates that cultured hepatocytes from adult rats expressed the IGF-II/Man-6-P receptor at the cell surface. The data from cross-linking experiments with ${ }^{125}$ I-IGF-II at tracer concentrations followed by immunoprecipitation with an antiserum raised against the human IGF-II/Man-6-P receptor revealed a single protein of an apparent molecular weight of about $300 \mathrm{kDa}$. Binding of ${ }^{125}$ I-IGF-II to this protein was sensitive to unlabelled IGF-II and Man-6-P. Furthermore, the affinity of IGF-II to the receptor, with half-maximal displacement of ${ }^{125} \mathrm{I}$ IGF-II occurring at IGF-II concentrations of about $1 \mathrm{nmol} / \mathrm{l}$, was similar to data obtained previously with the purified human IGF-II/Man-6-P receptor and with Chinese hamster ovary cells transfected with IGF-II/Man6-P receptor cDNA [9,39]. Apparently insulin was unable to interfere with the IGF-II/Man-6-P receptor of rat hepatocytes, this observation being consistent with results from previous studies using rat liver plasma membranes and other cells [8]. The IGF-II/Man-6-P receptor-mediated endocytosis of the lysosomal enzyme arylsulphatase A could be suppressed in the presence of Man-6-P and IGF-II. Similar observations have been made in rat BRL 3A2 liver and C6 glial cells [40]. For these latter cells it was proposed that IGF-II decreased the affinity of the receptor for Man-6-P-containing ligands [29]. Because of limited amounts of labelled arylsulphatase $A$ in the present investigation it was not possible to evaluate IGF-IIdependent changes in receptor affinity for arylsulphatase A. Alternatively, receptor occupation with IGF-II could interfere with the Man-6-P binding site thus preventing binding and internalization of arylsulphatase $A$.
Metabolic actions of IGF-II were demonstrated in the present study that qualitatively resembled those of insulin. Like insulin, IGF-II elicited rapid cellular responses (e.g. stimulation of glycogen synthesis, AIB transport and glycolysis as well as inhibition of glycogenolysis). In addition, long-term regulated cellular responses, like induction of the regulatory enzymes glucokinase and pyruvate kinase, were affected by IGF-II. Furthermore, IGF-II showed glucagon-antagonistic effects. These metabolic actions of IGF-II were apparently not mediated through the IGF-II/Man-6-P receptor, since metabolic responses were elicited at IGF-II concentrations that exceeded those of insulin several fold. Half-maximal effects required IGF-II concentrations of about $10 \mathrm{nmol} / \mathrm{l}$, thus exceeding the affinity constant of IGF-II to its own receptor at least ten-fold. In addition, antibodies against the IGFII/Man-6-P receptor did not affect the stimulatory action of IGF-II on glycogen synthesis, while binding of ${ }^{125}$ I-IGFII to its receptor was markedly reduced. The same antibodies could block the endocytosis of arylsulphatase $\mathrm{A}$, a process dependent upon interaction with the IGF-II/Man6-P receptor. The potency of IGF-II in modulating metabolic cellular responses paralleled the binding affinity of IGF-II to the hepatocyte insulin receptor. Half-maximal displacement of ${ }^{125}$ I-insulin occurred at IGF-II concentrations of about $10 \mathrm{nmol} / \mathrm{l}$, in the range where half-maximal effects on metabolism and enzyme induction were observed. It is therefore tempting to explain the demon-

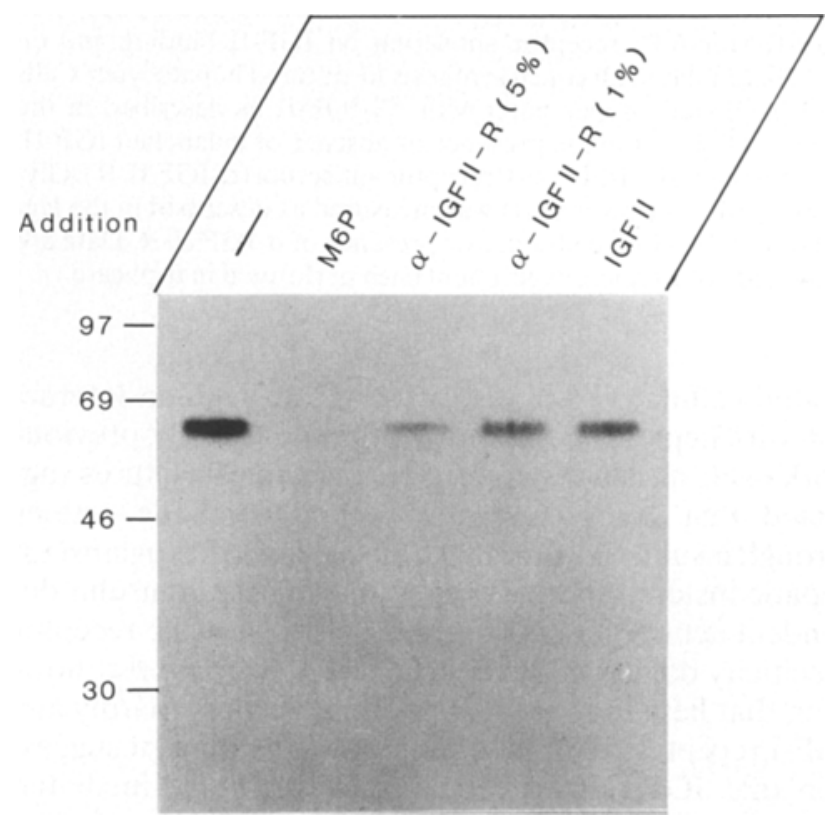

Fig.6. Effect of insulin-like growth factor II/mannose 6-phosphate (IGF-II/Man-6-P) receptor antiserum and IGF-II on uptake of arylsulphatase A in cultured hepatocytes. After 48 h of culture, cells were incubated with or without 1 or $5 \%$ IGF-II/M-6-P receptor antiserum $\left(\alpha-\right.$ IGF II-R) for $30 \mathrm{~min}$ at $37^{\circ} \mathrm{C}$. $\left[{ }^{35} \mathrm{~S}\right]$ Methionine-labelled secretions from cells overexpressing human arylsulphatase A were added and the cells incubated for further $60 \mathrm{~min}$ in the presence of receptor antiserum, Man-6-P $(5 \mathrm{mmol} / \mathrm{l})$ or IGF-II $(100 \mathrm{nmol} / \mathrm{l})$. Arylsulphatase A was immunoprecipitated from cell lysates and visualized after sodium dodecyl sulphate/polyacrylamide gel electrophoresis by fluorography. Numbers at the left margin refer to the positions of molecular mass standards (kilodaltons) 

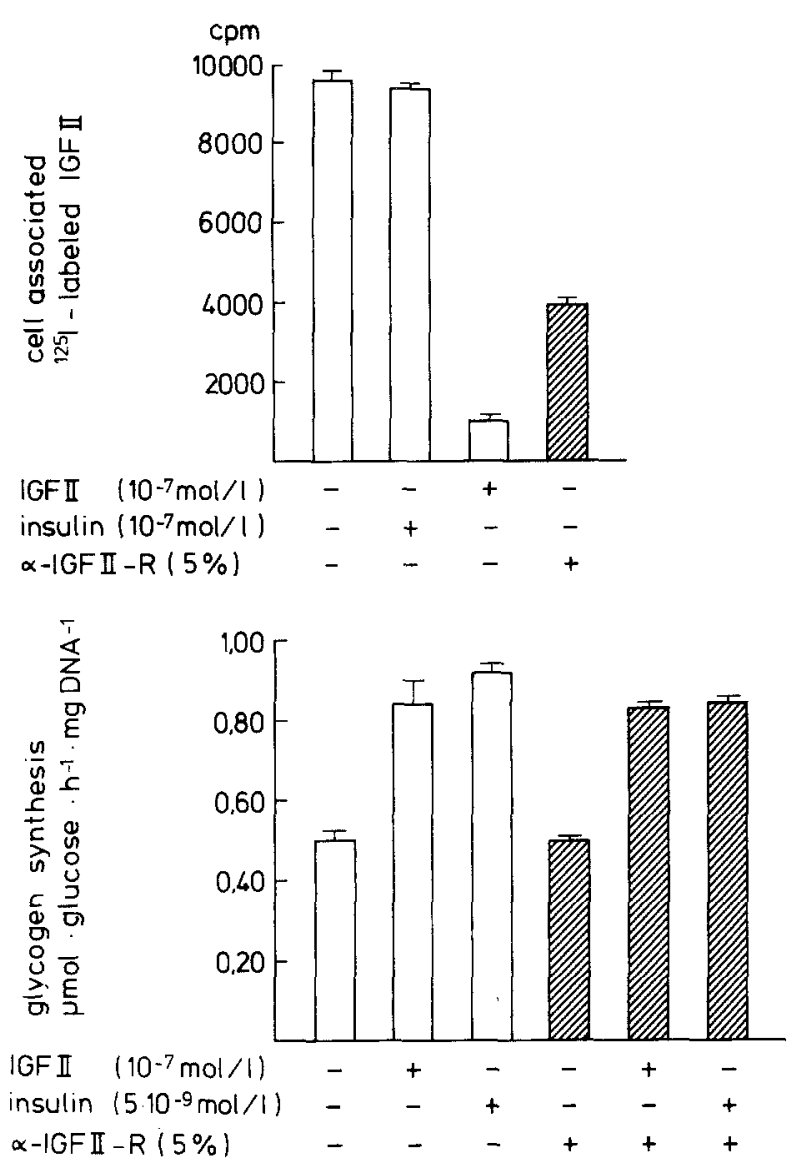

Fig. 7. Effect of insulin-like growth factor II/mannose 6-phosphate (IGF-II/Man-6-P) receptor antiserum on IGF-II binding and on IGF-II-stimulated glycogen synthesis in cultured hepatocytes. Cells were incubated (upper part) with ${ }^{125}$ I-IGF-II as described in the legend to Figure 1 in the presence or absence of unlabelled IGF-II, insulin or an IGF-II/Man-6-P receptor antiserum ( $\alpha$-IGF II-R). Glycogen synthesis (lower part) was measured as described in the legend to Figure 3 in the absence or presence of $\alpha$-IGF II-R. Data are mean $\pm \mathrm{SD}$ of a typical experiment each performed in triplicate

strated cellular responses to IGF-II through an interaction with hepatic insulin receptors. Additionally, previous work using adult rat hepatocytes in primary cultures suggested that IGF-I may also exert metabolic actions through insulin receptors [41]. Since antibodies against rat hepatic insulin receptors capable of blocking insulin-dependent actions have not yet been obtained, the receptor specificity could not be ascertained. It is of interest however, that hepatocytes from adult rats express hardly any IGF-I receptors [23], thus supporting the present suggestion that IGF-II metabolic actions might be mediated through insulin receptors. This conclusion is in contrast to data from previous studies particularly that observing a stimulatory action of IGF-II on glycogen synthesis [13]. Using HEP-G2 cells and specific antibodies against individual receptors for insulin, for IGF-I and IGF-II, Hari et al. suggested a signalling mechanism via the IGF-II/Man6-P receptor for the stimulation of glycogen synthesis. Interestingly, antibodies to the IGF-II/Man-6-P receptor demonstrated a stimulatory action per se. An explanation for this discrepancy with respect to the present observations is not obvious. However, differences in hormonal re- sponses between rat hepatocytes and hepatoma cell lines have been previously reported [42]. Several other studies support the present suggestion that cellular signalling for metabolic actions is, at least in adult rat hepatocytes, unlikely to involve the IGF-II/Man-6-P receptor [8, 19-22]. Finally, using IGF-II analogues with markedly reduced affinity to both the IGF-I and insulin receptor it has been demonstrated that "somatomedin-like" actions of IGF-II, e.g. stimulation of DNA synthesis, were not mediated through the IGF-II/Man-6-P receptor [43, 44].

The physiological role of the cell surface IGF-IL/Man6-P receptor in adulthood appears to be the binding and degradation of IGF-II as well as endocytosis of Man-6-Pcontaining ligands (lysosomal enzymes) thereby modulating their extracellular concentrations.

Acknowledgements. We are grateful to Ms. S.Zachmann and Ms. C. Scholz for excellent technical assistance. This work was supported by the Deutsche Forschungsgemeinschaft, Bonn-Bad Godesberg, FRG (SFB 236, B11 and Ha 1498/2-1).

\section{References}

1. Froesch ER, Zapf $\mathbf{J}$ (1985) Insulin-like growth factors and insulin: comparative aspects. Diabetologia 28: 485-493

2. Humbel RE (1990) Insulin-like growth factors I and II. Eur J Biochem 190: 445-462

3. Adams SO, Nissley SP, Handwerger S, Rechler MM (1983) Developmental patterns of insulin-like growth factor-I and -II synthesis and regulation in rat fibroblasts. Nature 302: 150-153

4. Stylianopoulou F, Efstratiadis A, Herbert J, Pintar J (1988) Pattern of insulin-like growth factor II gene expression during rat embryogenesis. Development 103: 497-506

5. DeChiara TM, Efstratiadis A, Robertson EJ (1990) A growthdeficiency phenotype in heterozygous mice carrying an insulinlike growth factor II gene disrupted by targeting. Nature 345 : $78-80$

6. Zapf J, Schoenle E, Froesch ER (1978) Insulin-like growth factors I and II: some biological actions and receptor binding characteristics of two purified constituents of non-suppressible insulin-like activity of human serum. Eur J Biochem 87: 285-296

7. Zapf J, Hauri C, Waldvogel M, Froesch ER (1986) Acute metabolic effects and half-lives of intravenously administered insulinlike growth factors I and II in normal and hypophysectomized rats. J Clin Invest 77: 1768-1775

8. Mottola C, Czech MP (1984) The type II insulin-like growth factor receptor does not mediate increased DNA synthesis in $\mathrm{H}-35$ hepatoma cells. J Biol Chem 259: 12705-12713

9. Rechler MM, Nissley SP (1985) The nature and regulation of the receptors for insulin-like growth factors. Ann Rev Physiol 47: 425-442

10. Roth RA (1988) Structure of the receptor for insulin-like growth factor II: the puzzle amplified. Science 239: 1269-1271

11. Morgan DO, Edman JC, Standring DN et al. (1987) Insulin-like growth factor II receptor as a multifunctional binding protein. Nature 329: 301-307

12. von Figura K, Hasilik A (1986) Lysosomal enzymes and their receptors. Ann Rev Biochem 55: 167-193

13. Hari J, Pierce SB, Morgan DO, Sara V, Smith MC, Roth RA (1987) The receptor for insulin-like growth factor II mediates an insulin-like response. EMBO J 6: 3367-3371

14. Shimizu M, Webster C, Morgan DO, Blau HM, Roth RA (1986) Insulin and insulin-like growth factor receptors and responses in cultured human muscle cells. Am J Physiol 251: E611-E615

15. Nishimoto I, Ohkuni Y, Ogata E, Kojima I (1987) Insulin-like growth factor II increases cytoplasmatic free calcium in compe- 
tent $\mathrm{Balb} / \mathrm{c} 3 \mathrm{~T} 3$ cells treated with epidermal growth factor. Biochem Biophys Res Commun 142: 275-286

16. Rogers SA, Hammerman MR (1989) Mannose 6-phosphate potentiates insulin-like growth factor II-stimulated inositol trisphosphate production in proximal tubular basolateral membranes. J Biol Chem 264: 4273-4276

17. Tally M, Li CH, Hall K (1987) IGF-2 stimulated growth mediated by the somatomedin type 2 receptor. Biochem Biophys Res Commun 148: 811-816

18. Murayama Y, Okamoto T, Ogata E et al. (1990) Distinctive tegulation of the functional linkage between the human cation-independent mannose 6-phosphate receptor and GTP-binding proteins by insulin-like growth factor II and mannose 6-phosphate. J Biol Chem 265: 17456-17462

19. Czech MP (1989) Signal transmission by the insulin-like growth factors. Cell 59:235-238

20. Zapf J, Schoenle E, Waldvogel M, Sand I, Froesch ER (1981) Effect of trypsin treatment of rat adipocytes on biological effects and binding of insulin and insulin-like growth factors. Eur $\mathbf{J}$ Biochem 113: 605-609

21. Kiess W, Haskell JF, Lee L et al. (1987) An antibody that blocks insulin-like growth factor (IGF) binding to the type II IGF receptor is neither an agonist nor an inhibitor of IGF-stimulated biologic responses in L6 myoblasts. J Biol Chem 262: 12745-12751

22. Sinha MK, Buchanan C, Raineri-Maldonado Cet al. (1990) IGFII receptors and IGF-II-stimulated glucose transport in human fat cells. Am J Physiol 258: E534-E542

23. Caro JF, Poulos J, Ittoop O, Pories WJ, Flickinger EG, Sinha MK (1988) Insulin-like growth factor I binding in hepatocytes from human liver, human hepatoma, and normal, regenerating, and fetal rat liver. J Clin Invest 81: 976-981

24. Waheed A, Hasilik A, von Figura K (1982) Synthesis and processing of arylsulfatase $A$ in human skin fibroblasts. HoppeSeyler's Z Physiol Chem 363: 425-430

25. von Figura K, Gieselmann V, Hasilik A (1984) Antibody to mannose 6-phosphate specific receptors induces receptor deficiency in human fibroblasts. EMBO J 3: 1281-1286

26. Katz NR, Nauck MA, Wilson PT (1979) Induction of glucokinase by insulin under the permissive action of dexamethasone in primary rat hepatocyte cultures. Biochem Biophys Res Commun 83: $23-29$

27. Fleig WE, Nöther-Fleig $\mathbf{G}$, Steudter S, Enderle D, Ditschuneit $\mathbf{H}$ (1985) Regulation of insulin binding and glycogenesis by insulin and dexamethasone in cultured rat hepatocytes. Biochem Biophys Acta 847: 352-361

28. Braulke T, Gartung C, Hasilik A, von Figura K (1987) Is movement of mannose 6-phosphate-specific receptor triggered by binding of lysosomal enzymes? J Cell Biol 104: 1735-1742

29. Braulke T, Tippmer S, Chao HJ, von Figura K (1990) Insulin-like growth factors I and II stimulate endocytosis but do not affect sorting of lysosomal enzymes in human fibroblasts. J Biol Chem 265: 6650-6655

30. Chaiken RL, Moses AC, Usher P, Flier JS (1986) Insulin stimulation of aminoisobutyric acid transport in human skin fibroblasts is mediated through both insulin and type I insulin-like growth factor receptors. J Clin Endocrinol Metab 63: 1181-1185

31. Probst I, Schwartz P, Jungermann K (1982) Induction in primary culture of "gluconeogenic" and "glycolytic" hepatocytes re- sembling periportal and perivenous cells. Eur J Biochem 126: 271-278

32. Seubert W, Huth W (1965) On the mechanism of gluconeogenesis and its regulation. II. The mechanism of gluconeogenesis from pyruvate and fumarate. Biochem Z 343: 176-191

33. Oliver IT, Edwards AM, Pitot HC (1978) Hormonal regulation of phoshoenolpyruvate carboxykinase in primary cultures of adult-rat liver parenchymal cells. Eur J Biochem 87: 221-227

34. Stein C, Gieselmann V, Kreysing J et al. (1989) Cloning and expression of human arylsulfatase A. J Biol Chem 264: 1252-1259

35. Braulke T, Hille A, Huttner WB, Hasilik A, von Figura K (1987) Sulfated oligosaccharides in human lysosomal enzymes. Biochem Biophys Res Commun 143: 178-185

36. Spence JT, Merill MJ, Pitot HC (1981) Role of insulin, glucose, and cyclic GMP in the regulation of glucokinase in cultured hepatocytes. J Biol Chem 256: 1598-1603

37. Noguchi T, Inoue H, Tanaka T (1982) Regulation of rat liver Ltype pyruvate kinase mRNA by insulin and by fructose. Eur J Biochem 128: 583-588

38. Gartung C, Braulke T, Hasilik A, von Figura K (1985) Internalization of blocking antibodies against mannose 6-phosphate specific receptors. EMBO J 4: 1725-1730

39. Roth RA, Steele-Perkins G, Hari J et al. (1988) Insulin and insulin-like growth factor receptors and responses. In: Cold Spring Harbor Symposia on quantitative biology Vol.LIII, Molecular biology of signal transduction. Cold Spring Harbour Laboratory, Cold Spring Harbour, pp 537-543

40. Kiess W, Thomas CL, Greenstein LA et al. (1989) Insulin-like growth factor II (IGF-II) inhibits both the cellular uptake of $\beta$ galactosidase and the binding of $\beta$-galactosidase to purified IGFII/mannose 6-phosphate receptor. J Biol Chem 264: 4710-4714

41. Hartmann H, Schmitz F, Christ B, Jungermann K, Creutzfeldt W (1990) Metabolic actions of insulin-like growth factor-I in cultured hepatocytes from adult rats. Hepatology 12: 1139-1143

42. Runge D, Schmidt H, Christ B, Jungermann K (1991) Mechanism of the permissive action of dexamethasone on the glucagondependent activation of the phosphoenolpyruvate carboxykinase gene in cultured rat hepatocytes. Eur J Biochem 198: 641-649

43. Bürgisser DM, Roth BV, Giger R et al. (1991) Mutants of human insulin-like growth factor II with altered affinities for the type 1 and type 2 insulin-like growth factor receptor. J Biol Chem 266: 1029-1033

44. Beukers MW, Oh Y, Zhang H, Ling N, Rosenfeld RG (1991) $\left[\mathrm{Leu}^{27}\right]$ Insulin-like growth factor II is highly selective for the type-II IGF receptor in binding, cross-linking and thymidine incorporation experiments. Endocrinology 128: 1201-1203

Received: 1 July 1991

and in revised form: 31 October 1991

Dr. H. Hartmann

Medizinische Universitätsklinik

Robert-Koch-Str. 40

W-3400 Goettingen

FRG 